\title{
Livestock forage conditioning: Bluebunch wheatgrass, Idaho fescue, and bottlebrush squirreltail
}

\author{
DAVE GANSKOPP, TONY SVEJCAR, AND MARTY VAVRA
}

Authors are Range Scientists, USDA-ARS, Eastern Ore. Agr. Res. Ctr., 67826-A Hwy. 205, Burns, Ore. 97720 and Team Leader, Forestry and Range Sci. Lab., PNWRS-FS, 140/ Gekeler Lane, La Grande, Ore. 97850 / Prof., Eastern Ore. Agr. Res. Ctr., 67826-A Hwy. 205, Burns, Ore. 97720.

\section{Abstract}

Research on Anderson and Scherzinger's hypothesis that spring cattle grazing can positively affect subsequent nutritional characteristics of grasses have generated mixed results. Our objectives were: 1) to evaluate fall/winter nutritional indices of bluebunch wheatgrass (Agropyron spicatum [Pursh] Scribn. \& Smith), Idaho fescue (Festuca idahoensis Elmer), and bottlebrush squirreltail (Sitanion hystrix (Nutt.) Smith) in ungrazed, lightly grazed (33\% utilization), or heavily grazed ( $69 \%$ utilization) pastures stocked with cattle at the boot stage of growth; and 2) to quantify opportunity costs of applying those treatments on fall standing crop. Compared with ungrazed stands, light and heavy spring grazing decreased September standing crop by 32 and $67 \%$, respectively. September/December crude protein (CP) among heavily grazed grasses $(\bar{x}=6.9 \%)$ exceeded ungrazed controls $(\bar{x}=3.9 \%)$ for 11 of 12 comparisons. Crude protein of lightly grazed grasses $(\bar{x}=5.2 \%)$ was higher than ungrazed controls for 6 of 12 comparisons. Herbage was more nutritious during the drier of the 2 years sampled. Among grazed treatments, fall/winter CP measures were highest for bottlebrush squirreltail $(\overline{\mathbf{x}}=$ $\mathbf{7 . 4 \%}$ ), intermediate for Idaho fescue $(5.9 \%)$, and lowest for bluebunch wheatgrass $(0=4.9 \%)$. In fall/winter, herbage was most digestible in heavily grazed paddocks $(\bar{x}=59 \%)$, intermediate in lightly grazed paddocks $(\bar{x}=53 \%)$, and least digestible in ungrazed areas $(\bar{x}=49 \%)$. Light and heavy spring cattle grazing can augment fall/winter forage quality of bluebunch wheatgrass, Idaho fescue, and bottlebrush squirreltail. Spring grazing reduces subsequent standing crop, but remaining forage will be nutritionally superior to herbage in ungrazed stands.

Key Words: Agropyron spicatum, Festuca idahoensis, Sitanion hystrix, beef cattle, big game, winter range, wildlife, habitat, diet quality

In a study to evaluate morphological and physiological effects of cattle grazing crested wheatgrass (Agropyron cristatum (L.) Gaertn), Hyder and Senva (1963) noted spring removal of elevated meristems stimulated a growth of new tillers that did not progress through their typical reproductive phases of development. Soil moisture is usually exhausted by mid-summer in the region, and there is typically little increase in standing crop after

Eastern Oregon Agricultural Research Center is jointly operated by the Oregon Agr. Exp. Sta. of Oregon State Univ, and the USDA-Agricultural Research Service. Manuscript accepted 19 Nov. 03.
Resumen

La investigación sobre la hipótesis de Anderson y Scherzinger de que el apacentamiento del ganado en primavera puede afectar positivamente las características nutricionales subsecuentes de los zacates ha producido resultados mixtos. Nuestros objetivos fueron: 1) evaluar indices nutricionales de otoño/invierno de "Bluebunch wheatgrass" (Agropyron spicatum [Pursh] Scribn. \& Smith), "Idaho fescue" (Festuca idahoensis EImer) y "Bottlebrush squirreltail"' (Sitanion hystrix (Nutt.) Smith) en potreros sin apacentar, ligeramente apacentados $(33 \%$ de uti. lización) y fuertemente apacentados (69\% de utilización) cargados con ganado en la época de embuche (antes de la floración) y 2) cuantificar los costos de oportunidad de aplicar esos tratamientos en la biomasa en pie de otoño. Comparado con las poblaciones sin apacentar, el apacentamiento ligero y fuerte en Septiembre reducen la biomasa en pie en 32 y $67 \%$ respectiva. mente. En 11 de 12 comparaciones, el contenido de proteína cruda en Septiembre/Diciembre (CP) entre los zacates fuertemente apacentados $(\bar{x}=6.9 \%)$ excedió el control sin apacentamiento $(\bar{x}=3.9$ percent $)$. La proteína cruda de los zacates ligeramente apacentados $(\bar{x}=5.2 \%)$ fue mayor que la de los zacates control sin apacentar, esto en 6 de 12 comparaciones. El forraje fue más nutritivo en el año mas seco de los 2 años muestreados. Entre los tratamientos de apacentamiento, las mediciones de proteína cruda de otoño/invierno mas altas fueron para "Bottlebrush squirreltail" ( $\overline{\mathbf{x}}=7.4 \%)$, intermedias para Idaho fescue" $(5.9 \%)$ y el más bajo para "Bluebunch wheatgrass" ( $\bar{x}=$ 4.9\%). En Otoño/invierno el forraje fue mas digestible en los potreros apacentados fuertemente $(\overline{\mathbf{x}}=59 \%)$, intermedio en los apacentados ligeramente $(\bar{x}=53 \%)$ y la menor digestibilidad se detectó en las áreas control sin apacentar $(\bar{x}=49 \%)$. El apacentamiento ligero y fuerte del ganado puede aumentar la calidad del forraje en otoño/invierno del "Bluebunch wheatgrass", "Idaho fescue" $y$ "Bottlebrush squirreltail". El apacentamiento en primavera reduce la biomasa en pie subsecuente, pero el forraje remanente será nutritivamente superior al forraje de las áreas sin apacentar.

the first of July. Hyder and Senva (1963) speculated the resulting cured, but leafy, herbage would provide palatable and nutritious late-summer or fall forage for cattle when lower-quality deferred stands of grass could not sustain livestock gains. Subsequently, Anderson and Scherzinger (1975) reported an instance in northcentral Oregon where early-season cattle grazing may have elevated forage quality and palatability of grasses and caused a greater than 4 -fold increase in the numbers of wintering elk 
(Cervus elaphus nelsoni Bailey) frequenting the area. Conversely, however, Skovlin et al. (1983) found spring cattle grazing did not promote subsequent use by elk in Washington. While none of these studies quantified the nutritional characteristics of their forages, their premise of forage conditioning has become a widespread component of grazing management programs (Pitt 1986).

Several researchers subsequently explored the forage conditioning, hypothesis via clipping studies, with mixed results. Pitt (1986) found nutritional gains from spring defoliations of bluebunch wheatgrass (Agropyron spicatum [Pursh] Scribn. \& Smith), while WestenskowWall et al. (1994) and Wambolt et al. (1997) found no increase in fall forage quality. Clark et al. (1998a) applied midboot and early flowering clippings to bluebunch wheatgrass and detected significant increases in early November digestibility and crude protein (CP) content when compared with unclipped plants. More recently, Clark et al. (2000) applied sheep grazing during the boot stage to bluebunch wheatgrass and Idaho fescue (Festuca idahoensis Elmer) with treatments elevating November CP levels by 1 and 1.3 percentage points, respectively. In vitro dry matter (DM) digestibility of bluebunch wheatgrass was increased by 4.3 percentage points (Clark et al. 2000). Similarly, Hobbs et al. (1996) found grazing by elk elevated the live-to-dead ratios of spring forage, resulting in slight but significant increases in nitrogen content and digestibility. Dietary digestibility and fiber contents of forages, however, did not change with elk grazing treatments.

Given the mixed results of these investigations, we designed a study to test the forage conditioning hypothesis with cattle grazing. Our objectives were: 1 ) to evaluate subsequent fall and winter nutritional characteristics of bluebunch wheatgrass, Idaho fescue, and bottlebrush squirreltail (Sitanion hystrix (Nutt.) Smith) in stands that were ungrazed, lightly grazed (stocked with 2 cows), or heavily grazed (stocked with 4 cows) by cattle during the boot-stage of grass development, and 2) to quantify the fall standing crop costs of implementing these same treatments.

\section{Methods}

\section{Study area}

A detailed history, vegetation list, and soils description of the study area $\left(43^{\circ} 37^{\prime} \mathrm{N} 119^{\circ} 24^{\prime} \mathrm{W}\right.$, elevation $\left.1,584 \mathrm{~m}\right)$ can be found in Ganskopp et al. (1999). Briefly, the area occupied Bureau of Land Management (BLM)-administered, pineforest/sagebrush-steppe transition range, providing spring/summer forage for beef cattle and wintering deer (Odocoileus hemionus) and elk near Burns, Ore. Vegetation included a scattered western juniper (Juniperus occidentalis Hook) overstory, a shrub layer characterized by mountain big sagebrush (Artemisia tridentata subspp. vaseyana (Rydb.) Beetle) with a minor bitterbrush (Purshia tridentata (Pursh) DC) component, and a herbaceous layer dominated by bluebunch wheatgrass, Idaho fescue, bottlebrush squirreltail, and Thurber's needlegrass (Stipa thurberiana Piper).

\section{Pastures and grazing schedules}

This study was a randomized complete block design having 3 treatments and 3 replications with individual pastures $(\mathrm{N}=$ 9) functioning as experimental units. Treatments included 3 pastures that were: 1) lightly-grazed by cattle, 2) heavily grazed by cattle, and 3) ungrazed controls. Because treatments were not re-randomized between years (1998 and 1999) findings reflect cumulative effects across 2 successive growing seasons.

Size of grazed paddocks ranged from 0.6 to $0.9 \mathrm{ha}$, and ungrazed controls were between 1.4 and $1.6 \mathrm{ha}$. For the 1998 trial, we used 18 dry Hereford $x$ Angus cows with a mean body weight of $453 \mathrm{~kg}$ ( $\mathrm{SE}=$ 26). Lightly-grazed paddocks supported 2 cows, and heavily-grazed paddocks supported 4 , with the grazing portion of the trial beginning on 21 May and lasting for 12 days. In 1999, 18 dry cows were drawn from a group scheduled for culling, and mean body weight was slightly heavier $(\bar{x}$ $=567 \mathrm{~kg}, \mathrm{SE}=14.5$ ). Paddocks were stocked on 4 June 1999 and grazing continued for 10 days. Our goal in these trials was to stock the heavily grazed pastures until at least $50 \%$ of the herbaceous forage mass had been utilized.

In conjunction with another study, these same pastures were stocked at half the rate used in this study in 1997. Just before pastures were stocked in 1998, standing crop ranged between 754 and $779 \mathrm{~kg} \mathrm{ha}^{-1}(\bar{x}=$ (769) among the grazed and control units, with no significant differences $(P>0.05)$ detected among treatments.

\section{Forage sampling}

To characterize available herbage just before stocking, grasses and forbs were clipped to a $2.5-\mathrm{cm}$ stubble from ten, $1-\mathrm{m}^{2}$ plots in each pasture. Bagged materials were oven dried at $40^{\circ} \mathrm{C}$, weighed, composited by pasture, mixed in a large plastic tub, and subsampled (approximately 200 g) for later assessments of forage quality. Subsamples were ground to pass a 20 mesh screen and secured in plastic bags for storage at room temperature. Chemical assays included: crude protein $(\mathrm{CP}=$ Kjeldahl nitrogen x 6.25; AOAC 1984), neutral detergent fiber (NDF; Robertson and Van Soest 1981), and in vitro organic matter digestibility (IVOMD; AOAC 1990). To quantify levels of forage utilization after cattle were removed, standing crop was sampled again by clipping ten, 1$\mathrm{m}^{2}$ plots per pasture.

Herbage was sampled a third time the second week of September and a fourth time the third week of December. The September sampling was used to quantify standing crop available for fall and winter use by game or livestock and to assess nutritive content of the 3 major grasses. Again, materials were harvested from ten, $1-\mathrm{m}^{2}$ plots per pasture. Herbage was sorted among 4 categories (the 3 major grasses: bluebunch wheatgrass, Idaho fescue, bottlebrush squirreltail, and a fourth labeled "other"). These materials were oven dried at $40^{\circ} \mathrm{C}$, weights recorded, the grass samples were composited by species within each pasture, and the composited samples were ground and retained for subsequent chemical assays. A similar procedure was used with the December sampling, but materials were not weighed to quantify standing crop.

\section{Statistical procedures}

For variables quantified solely on an annual basis (i.e., measures of total standing crop, total standing crop forage quality indices, and levels of forage utilization), a split-plot analysis of variance was used to evaluate treatment, year, and interaction effects. Treatments ( $2 \mathrm{df})$ served as whole plots, with the block $x$ treatment interaction (4 df) used as error term 1 . Years were subplots, with year $(1 \mathrm{df})$ and the treatment $x$ year interaction $(2 \mathrm{df})$ tested with the residual error term $(6 \mathrm{df})$. This approach was used because sequences in time cannot be randomized, resulting in an inadvertent split-plot (Peterson 1985, Cody and Smith 1997). When effects were significant in the analyses of variance, single degree-of-freedom contrasts were used for mean separations between species on a given date.

For the September measures of standing crop, variation was partitioned among main effects of treatments $(2 \mathrm{df})$, species of grass and the "other" category ( $3 \mathrm{df})$, 
years (l $\mathrm{df}$ ), and their respective interactions using a factorial arrangement of treatments and species and a split-plot for year effects. Treatment, species, and the treatment $x$ species interaction $(6 \mathrm{df})$ were tested with the block $x$ treatment $x$ species (22 df) error term, while the year subplot, treatment $x$ year $(2 \mathrm{df})$, species $x$ year $(3$ $\mathrm{df}$ ), and the 3-way treatment $x$ species $x$ year interactions were tested with the residual error term ( $24 \mathrm{df})$. Again, mean separations between species on a given date employed single degree-of-freedom contrasts.

Last, for the September and December assays of forage quality (CP, NDF, and IVOMD), variation was partitioned among the main effects of treatments $(2 \mathrm{df})$, species of grass $(2 \mathrm{df})$, years $(1 \mathrm{df})$, sampling periods (Sept. and Dec. $(1 \mathrm{df})$, and their respective interactions using a factorial arrangement for treatments and species. Error term 1 (block $\mathrm{x}$ treatment $\mathrm{x}$ species (16 df)) was used to test treatment, species, and the treatment $x$ species interaction. Years were subplots ( $1 \mathrm{df}$ ) with treatment $x$ year $(2 \mathrm{df})$, species $x$ year $(2$ $\mathrm{df})$, and the treatment $x$ species $x$ year effects $(4 \mathrm{df})$ tested by the block $x$ treatment $\mathrm{x}$ species $\mathrm{x}$ year interaction $(18 \mathrm{df})$. Months were subsubplots, and the residual error term ( $36 \mathrm{df})$ used to test for month ( 1 $\mathrm{df})$, treatment $x$ month $(2 \mathrm{df})$, species $x$ month $(2 \mathrm{df})$, year $x$ month ( $1 \mathrm{df})$, the 3way interactions of treatment $x$ species $x$ month $(4 \mathrm{df})$, treatment $x$ year $x$ month $(2$ $\mathrm{df})$, species $x$ year $x$ month $(2 \mathrm{df})$, and the 4-way treatment $x$ species $x$ year $x$ month interaction (4 df) effects. Again, the splitplot approach was used because time series could not be randomized (Peterson 1985, Cody and Smith 1997). Mean separations were accomplished with single degree of freedom contrasts using Satterthwaite's approximation for estimating error degrees of freedom (Satterthwaite 1946). Statistical significance in all analyses was accepted at $\mathrm{P} \leq$ 0.05 . Throughout the manuscript, values following \pm symbols are standard errors (SE) of the mean.

\section{Results}

\section{Precipitation patterns}

Sneva (1982) determined crop-year forage accumulations in the region were most closely correlated with precipitation totals for the previous Sept.-June period. The weather station with the longest continuous record near our study site was on the Northern Great Basin Experimental Range (referenced as the Squaw Butte Experiment Station in N.O.A.A. (2001) records) some $29 \mathrm{~km}$ southwest and $161 \mathrm{~m}$ lower than our study site. Mean crop-year precipitation $(n=64)$ for the Experimental Range is $26.1 \mathrm{~cm}$, and accumulations for the 1998 and 1999 crop-years were 196 and $106 \%$ of average, respectively. Given the differences in elevation and vegetation between the Experimental Range and our study site, we speculate our research plots receive about $10 \mathrm{~cm}$ more precipitation annually than the Experimental Range.

There have been no studies addressing relationships among late summer or fall precipitation patterns and fall or winter green-up and yields of grasses in the region. Monthly precipitation totals for the 1998 and 1999 calendar years are found in Fig. 1. Monthly accumulations leading into the spring/summer growing seasons were average or above for both years. Conversely, August through December accumulations $(\overline{\mathrm{x}}=11.3 \mathrm{~cm})$, which probably figure prominently in the initiation of fall green-up of our grasses, were well below average for both years. We received $56 \%$ of average in the fall and early winter of 1998 and $36 \%$ of average in 1999.

\section{Pregrazing herbaceous standing crop, forage utilization, and forage quality}

Mean standing crop just before pastures were stocked was $590 \mathrm{~kg} \mathrm{ha}^{-1}$ and varied among treatments but not years. Pastures to be lightly stocked supported $657 \mathrm{~kg} \mathrm{ha}^{-1}$, while heavily stocked paddocks had a standing crop of $523 \mathrm{~kg} \mathrm{ha}^{-1}$. Prestocking standing crop measures probably did not reflect disparities in crop-year precipitation patterns because sampling occurred well before completion of the spring/summer growing season. Mean utilization was $33( \pm 10.1)$ percent in the lightly grazed paddocks and $69( \pm 9.1)$ percent in heavily stocked pastures. Pregrazing forage quality indices did not display any treatment or year effects. Mean CP, NDF, and IVOMD values were $11.5( \pm 0.6), 56.8( \pm 1.7)$, and $64.5( \pm 2.2)$ percent, respectively.

\section{September standing crop}

Total standing crop in early September displayed significant grazing treatment $(P$ $=0.006$ ) and year effects, but treatments responded similarly between years. Across years and among treatments, mean September standing crop was $757 \pm 78$, $518 \pm 169$, and $246 \pm 60 \mathrm{~kg} \mathrm{ha}^{-1}$ for the ungrazed controls, lightly grazed, and heavily grazed paddocks, respectively, with all treatment comparisons being significant. Across grazing treatments, mean standing crop was $686( \pm 112) \mathrm{kg} \mathrm{ha}^{-1}$ in September of 1998 and slightly less than half that amount $\left(328 \pm 79 \mathrm{~kg} \mathrm{ha}^{-1}\right)$ for the September 1999 sampling.

When total standing crop was partitioned among the 3 most prominent grasses and the remaining grasses and forbs (other) category, all main effects (treatment, species, and year) and the species $x$ year interaction were significant. Treatment $\mathrm{x}$ species, treatment $\mathrm{x}$ year, and

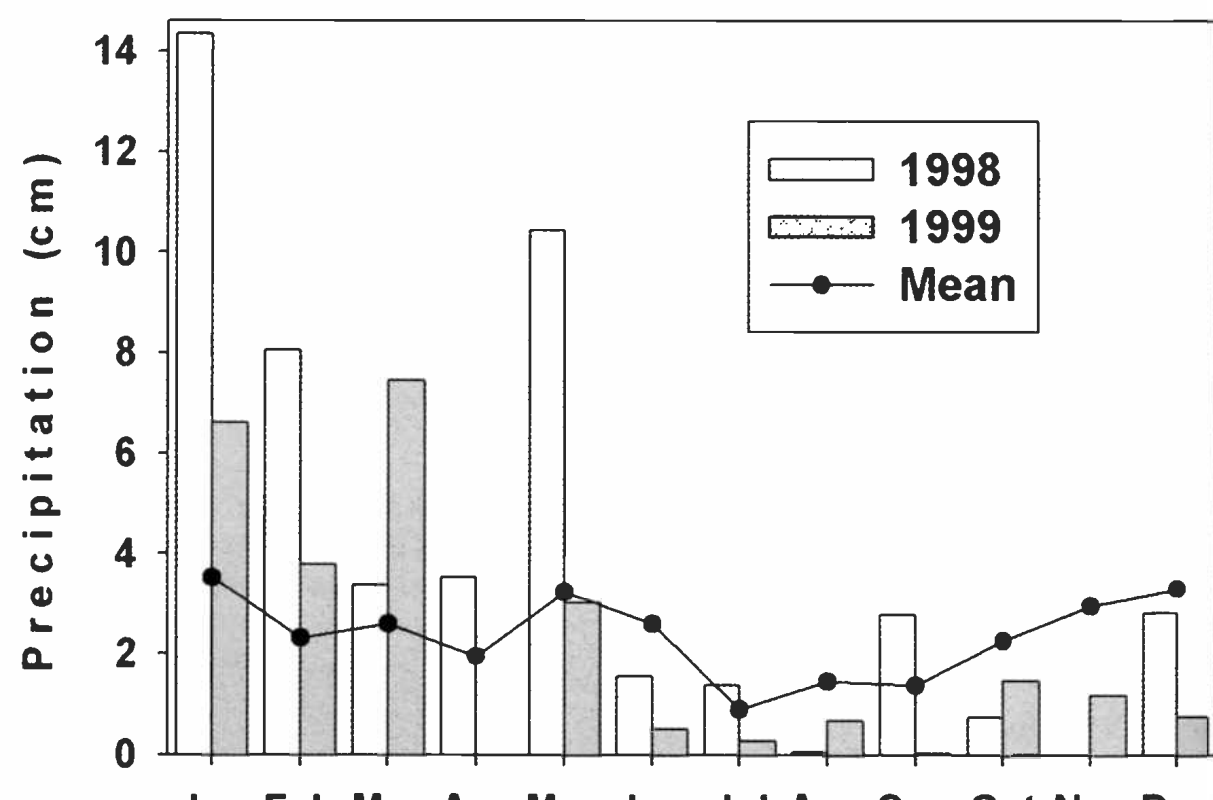

Jan Feb Mar Apr May Jun Jul Aug Sep Oct Nov Dec

Fig. 1. Monthly precipitation accumulations for 1998 and 1999 calendar years and the long. term monthly means $(N=64)$ at the Northern Great Basin Experimental Range in southeast Ore. 


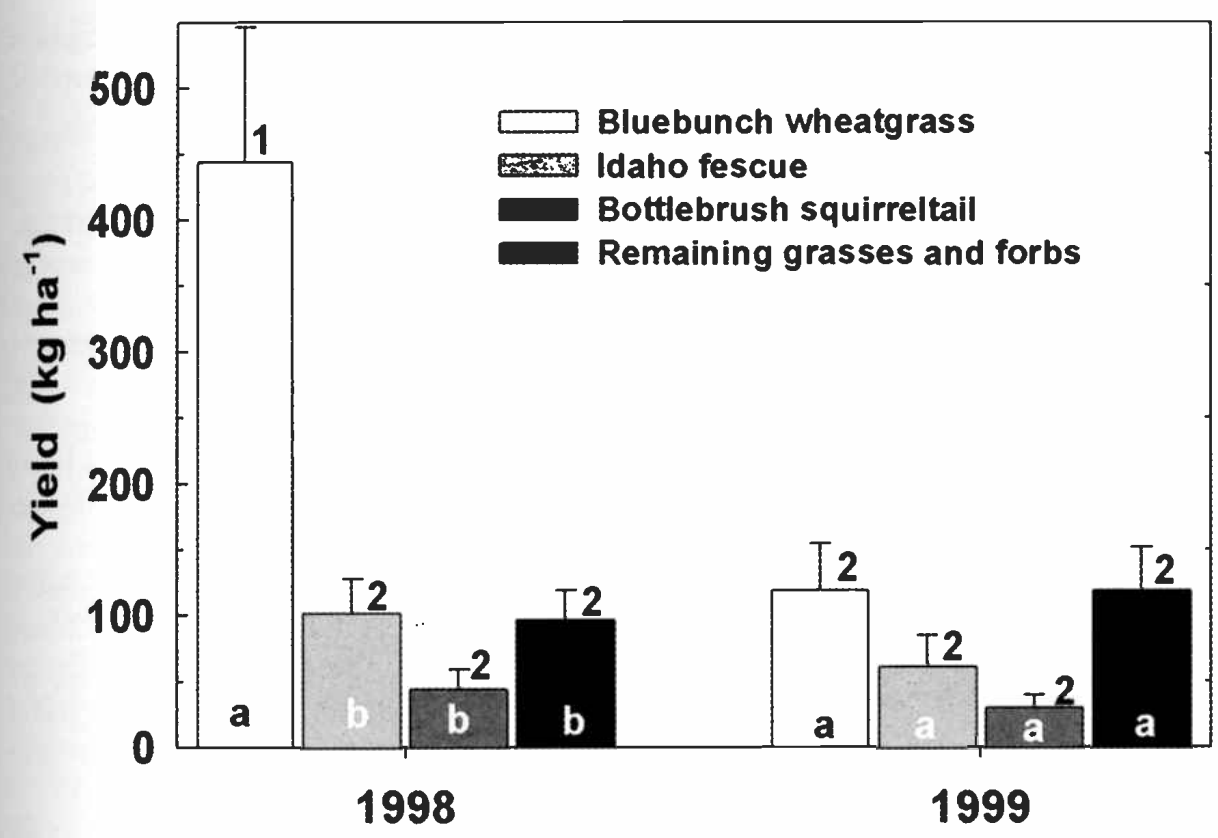

Fig. 2. Early September mean ( \pm SE) standing crop partitioned among bluebunch wheatgrass, Idaho fescue, bottlebrush squirreltail, and the remaining grasses and forbs in pastures that were ungrazed or conditioned with light and heavy cattle grazing in May of 1998 and 1999 near Burns, Ore. Means within a cluster sharing a common letter are not significantly different, and means of the same shade sharing a common numeral are not significantly different $(P>0.05)$.

the 3-way interaction effects were not significant. A preponderance of the interaction effects can be attributed to bluebunch wheatgrass and its more than 3 -fold difference in standing crop between September 1998 and 1999 (Fig. 2). There were no differences among the remaining forages either within or between years.

\section{Nutritional status of fall and winter regrowth}

Structure of analyses of variance and significant effects for NDF, CP, and IVOMD of the September and December samples are found in Table 1. Of the 3 forage quality indices, $\mathrm{CP}$ values were the most dynamic, with all main effects (treatment, species, year, and month) and a pre- ponderance of interactions being significant $(P \leq 0.05)$. With NDF and IVOMD, main effects of treatment, species, and year were significant, as were 2 of the 2 way interactions (Table 1).

\section{Crude protein}

Fall and winter $\mathrm{CP}$ concentration of the grasses ranged between 2.4 and 13.6 percent, with a mean of 5.4. The 3 components making the greatest contribution to $\mathrm{CP}$ variation were species (28\%), treatments (27\%), and the year $x$ month interaction (9\%). Given the complexities of interpreting a significant 4-way interaction, $\mathrm{CP}$ data for all treatments, species, years, and months are presented in Figure 3.

Across species and sampling dates, a consistent tendency among treatments was that ungrazed controls always ranked lowest for CP concentration, with lightly grazed grasses being slightly higher, and heavily grazed grasses consistently the highest (Fig. 3). Within species and sampling dates, CP concentration of heavily grazed forages exceeded that of ungrazed controls for 11 of 12 comparisons. The sole exception was bluebunch wheatgrass in September 1998 where no differences occurred among treatments. Crude protein of lightly grazed grasses exceeded percentages of the ungrazed controls for 6 of 12 comparisons. These included the last 3 sampling dates for Idaho fescue, December 1998 and September 1999 for bottlebrush squirreltail, and December 1998 for bluebunch wheatgrass. Between the 2 grazed treatments, $\mathrm{CP}$ percentages

Table 1. Analysis of variance components, degrees of freedom, percent of total variation contributed by effects, and their corresponding $P$ values for NDF, CP, and IVOMD of fall and winter regrowth from 3 grasses grazed by cattle during the boot stage of grass phenology near Burns, Ore. in 1998 and 1999. Bold $P$ values are significant $(\mathrm{P}<0.05)$.

\begin{tabular}{|c|c|c|c|c|c|c|c|}
\hline \multicolumn{2}{|l|}{ ANOVA component ${ }^{a}$} & \multicolumn{2}{|c|}{$\mathrm{NDF}^{2}$} & \multicolumn{2}{|c|}{$C \mathrm{P}^{3}$} & \multicolumn{2}{|c|}{ I VOM D } \\
\hline Source & DF & Variation $(\%)$ & $P$ value & Variation $(\%)$ & $P$ value & Variation (\%) & $P$ value \\
\hline Block & 2 & 1.4 & - & 0.2 & - & 0.1 & - \\
\hline Treatment & 2 & 31.3 & $<0.001$ & 40.2 & $<0.001$ & 17.5 & $<0.001$ \\
\hline Species & 2 & 28.4 & $<0.001$ & 16.1 & $<0.001$ & 20.9 & $<0.001$ \\
\hline Treatment $\mathrm{x}$ Species & 4 & 2.9 & 0.111 & 1.8 & 0.023 & 0.8 & 0.207 \\
\hline Error 1 & 16 & 1.3 & - & 0.5 & - & 0.5 & - \\
\hline Year & 1 & 5.8 & 0.018 & 8.5 & $<0.001$ & 13.6 & $<0.001$ \\
\hline Treatment $x$ Year & 2 & 2.4 & 0.086 & 3.9 & $<0.001$ & 4.8 & 0.006 \\
\hline Species $\mathrm{x}$ Year & 2 & 3.5 & 0.035 & 1.8 & 0.019 & 1.4 & 0.164 \\
\hline Treatment $x$ Species $x$ Year & 4 & 1.2 & 0.269 & 0.1 & 0.865 & 0.2 & 0.876 \\
\hline Error 2 & 18 & 0.9 & - & 0.4 & - & 0.7 & - \\
\hline Month & 1 & 5.4 & 0.004 & 5.6 & $<0.001$ & 2.8 & 0.060 \\
\hline Treatment x Month & 2 & 1.7 & 0.062 & 2.3 & $<0.001$ & 0.3 & 0.639 \\
\hline Species x Month & 2 & 4.7 & 0.001 & 0.7 & 0.045 & 5.6 & 0.002 \\
\hline Year x Month & 1 & 5.9 & 0.003 & 13.8 & $<0.001$ & 25.3 & $<0.001$ \\
\hline Treatment $x$ Species $\times$ Month & 4 & 0.1 & 0.964 & 0.1 & 0.869 & 0.5 & 0.592 \\
\hline Treatment $\mathrm{x}$ Year $\mathrm{x}$ Month & 2 & 0.6 & 0.358 & 2.4 & $<0.001$ & 1.5 & 0.145 \\
\hline Species x Year x Month & 2 & 1.1 & 0.169 & 0.8 & 0.027 & 2.2 & 0.068 \\
\hline Treatment $\mathrm{x}$ Species $\mathrm{x}$ Year $\mathrm{x}$ Month & 4 & 0.7 & 0.294 & 0.6 & 0.050 & 0.4 & 0.715 \\
\hline Error 3 & 36 & 0.6 & - & 0.2 & - & 0.8 & - \\
\hline
\end{tabular}

Analysis of variance component

${ }^{2}$ Neutral detergent fiber

${ }^{3}$ Crude protein

${ }^{4}$ In vitro organic matter disappearance 


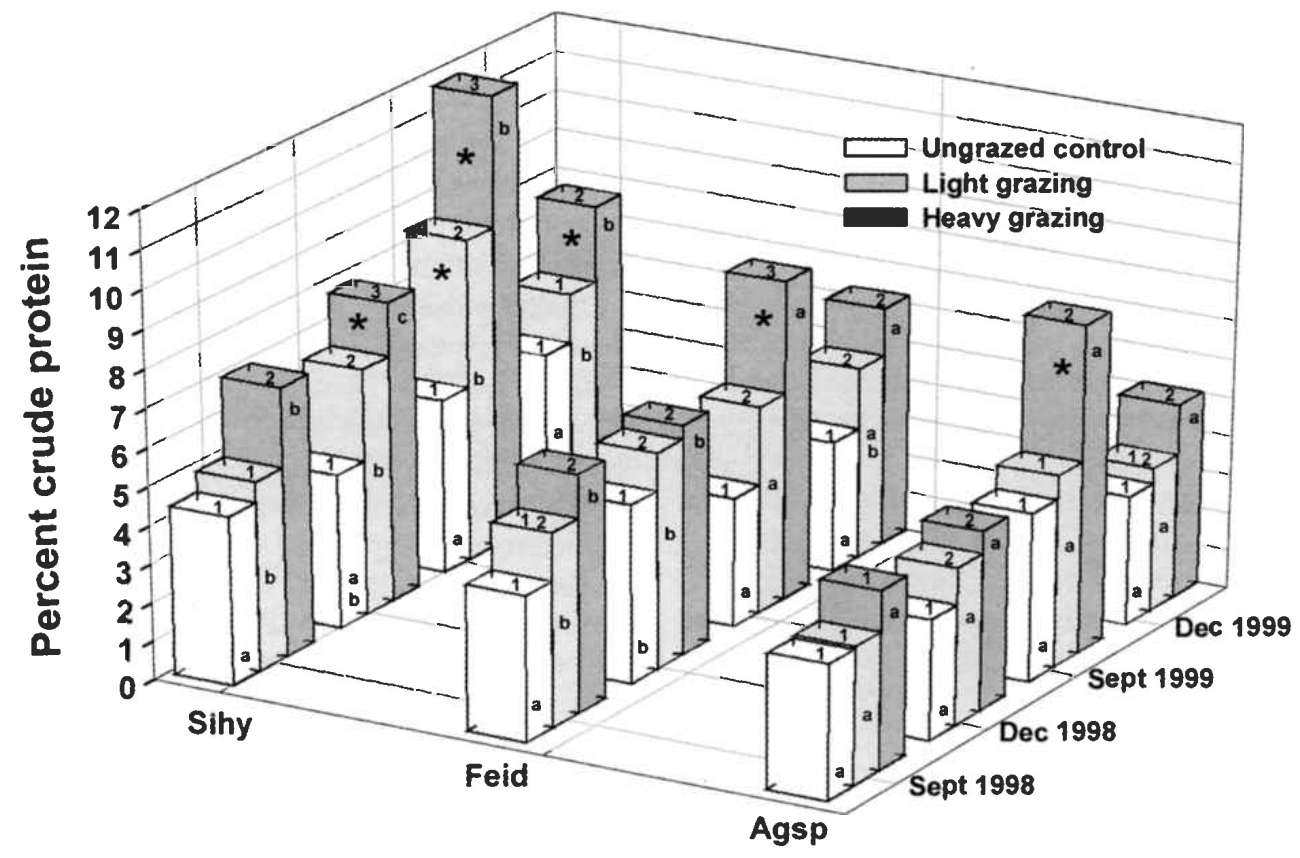

Fig. 3. September and December mean ( \pm SE) crude protein content of bluebunch wheatgrass (Agsp), Idaho fescue (Feid), and bottlebrush squirreltail (Sihy) herbage in ungrazed, lightly grazed, and heavily grazed pastures on big game winter range near Burns, Ore. in 1998 and 1999. Treatment means within a species and sampling period (groups within a column) sharing a common numeral are not significantly different $(P>0.05)$. Species means within a treatment and sampling period (rows) sharing a common letter are not significantly different $(\mathrm{P}>0.05)$. Means having a " $*$ " symbol $\geq 7.5 \%$ crude protein.

were consistently higher for bottlebrush squirreltail in heavily grazed paddocks than in lightly grazed units. Crude protein of heavily grazed Idaho fescue and bluebunch wheatgrass significantly exceeded percentages among lightly grazed paddocks on only 1 date (Sept. 1999).

Among species and within sampling dates and treatments, CP concentration of grazed bottlebrush squirreltail always exceeded grazed bluebunch wheatgrass $\mathrm{CP}$ concentrations (Fig. 3). Grazed bottlebrush squirreltail $\mathrm{CP}$ concentrations were greater than grazed Idaho fescue for 4 of 8 comparisons. These were the heavy grazing treatment of December 1998, light and heavy grazing treatments of September 1999, and the heavy grazing treatment of December 1999. Crude protein percentages of grazed Idaho fescue where higher than grazed bluebunch wheatgrass in 1998 but similar in 1999. With 1 exception, CP concentrations of ungrazed controls were similar among species. The exception occurred in December 1998 when Idaho fescue had a higher CP content $(4.7 \pm 0.25 \%)$ than bluebunch wheatgrass $(3.1 \pm 0.35 \%)$.

\section{Neutral detergent fiber}

Mean NDF concentration was $66.1 \%$ and ranged from 56 to $75 \%$. The 3 analysis of variance components making the exhibited differences between years, and bluebunch wheatgrass displayed significant seasonal differences between September and December. September
NDF values differed by 2.7 percentage points between years, while December means were similar (Table 2).

\section{In vitro organic matter disappearance}

In vitro organic matter disappearance ranged from 33.8 to $72.5 \%$, with a mean of 53.5. Analyses of variance results closely mirrored NDF findings (Table 1), with main effects of treatments, species, and years being significant. Of these effects, treatments did not respond similarly between years, species means were not similar between months, and monthly means varied between years. The 3 largest contributors to total variation were species and treatment main effects and the year $x$ month interaction. Together these accounted for $64 \%$ of total variation (Table 1).

Among treatments, mean IVOMD in the lightly grazed pastures was $47 \%$ in 1998 and $58 \%$ in 1999. Mean IVOMD was similar between years for both the ungrazed and heavily grazed treatments (Table 3 ). IVOMD of heavily grazed grasses was $59 \%$ in 1998 and significantly greater than ungrazed and lightly grazed treatments. In 1999, however, IVOMD of both of the grazed treatments exceeded ungrazed controls by about 10 percentage points. Among species, bluebunch wheatgrass was consistently less digestible than Idaho fescue and bottlebrush squirreltail. In vitro organic matter disappearance remained relatively stable from September to December for Idaho fescue and bottlebrush squirreltail, but declined by about 4 percentage points for bluebunch wheatgrass (Table 3 ). Among months and years, IVOMD of forages increased 5.7 percentage points between September and December in 1998 and decreased about 7 percentage points over the same interval in 1999.

Table 2. Species $\mathrm{x}$ month, species $\mathrm{x}$ year, and year $\mathrm{x}$ month interactions of percent neutral detergent fiber of bluebunch wheatgrass, Idaho fescue, and bottlebrush squirreltail grazed by cattle at the boot stage of grass phenology and sampled the subsequent September and December on big game winter range near Burns, Ore. in 1998 and 1999. Paired "bold font" means within a col. umn are significantly different $(\mathrm{P}<\mathbf{0 . 0 5})$. Species means within a year and monthly means with in a year sharing a common letter are not significantly different $(P>0.05)$.

\begin{tabular}{lcccll}
\hline \hline $\begin{array}{l}\text { Effect } \\
\text { Year }\end{array}$ & $\begin{array}{c}\text { Bluebunch } \\
\text { wheatgrass }\end{array}$ & $\begin{array}{c}\text { Species } \\
\text { Idaho } \\
\text { fescue }\end{array}$ & $\begin{array}{c}\text { Bottlebrush } \\
\text { squirreltail }\end{array}$ & September & December \\
\hline 1998 & $69.7 \pm 0.8 \mathrm{a}$ & $64.9 \pm 0.8 \mathrm{~b}$ & $\mathbf{6 5 . 7} \pm \mathbf{0 . 8 b}$ & $\underline{\mathbf{6 6 . 8} \pm \mathbf{0 . 6 a}}$ & $\underline{66.8} \pm 0.8 \mathrm{a}$ \\
1999 & $68.3 \pm 0.7 \mathrm{a}$ & $65.4 \pm 1.1 \mathrm{~b}$ & $\mathbf{6 2 . 7} \pm \mathbf{0 . 9 c}$ & $\underline{\mathbf{6 4 . 1} \pm \mathbf{0 . 9 a}}$ & $\underline{66.8} \pm 0.7 \mathrm{~b}$ \\
Season & & & & - & - \\
Sept & $\mathbf{6 7 . 3} \pm \mathbf{0 . 8 \mathrm { a }}$ & $65.5 \pm 1.1 \mathrm{~b}$ & $63.6 \pm 1.1 \mathrm{c}$ & - & - \\
Dec. & $\mathbf{7 0 . 7} \pm \mathbf{0 . 1 a}$ & $64.8 \pm 0.8 \mathrm{~b}$ & $64.8 \pm 0.9 \mathrm{~b}$ & - & \\
\hline
\end{tabular}




\section{Discussion}

\section{September total standing crop:}

\section{opportunity costs}

Typically, all but the earliest of growing-season defoliations among cool-season caespitose grasses cause some depression of growth or peak standing crop (Bedell 1973, Ganskopp 1998) and may affect some reduction in plant basal area as well (Clark et al. 1998b). The earliest defoliations, however, remove only leafy materials, do not suppress development of reproductive culms, and have negligible effects on late-season forage quality (Pitt 1986). Given these effects, one should most likely expect some depression of herbage yield if grazing applications are late enough to affect a positive change in nutrient content.

With the assumption that our grazed and control pastures had the same potential yields, we can explore some of the effects that treatments imposed on fall standing crop and total annual yield. Across years and among treatments, mean September standing crop was $757 \pm 78,518 \pm 169$, and $246 \pm 60 \mathrm{~kg} \mathrm{ha}^{-1}$ for ungrazed, lightly grazed, and heavily grazed paddocks, respectively. In September, the control minus lightly grazed difference in total standing crop was approximately $239 \mathrm{~kg}$ $\mathrm{ha}^{-1}$. Our before-and-after grazing samples suggested cattle were responsible for removal or disappearance of $228 \mathrm{~kg} \mathrm{ha}^{-1}$. This amounts to about $95 \%$ of the control versus lightly grazed difference in September, so we were unable to account for about $5 \%$ of the treatment difference. Some of this 5\% may have been converted to litter via trampling or shattering or was simply growth that did not occur if moisture and nutrients were assimilated by competing trees and shrubs. Whatever the case, standing crop available to wintering game was reduced about $32 \%$ by our lightgrazing treatment.

The September control (757 kg ha-1) versus heavily grazed $\left(245.8 \mathrm{~kg} \mathrm{ha}^{-1}\right)$ difference was $511 \mathrm{~kg} \mathrm{ha}^{-1}$, resulting in about a $68 \%$ depression of standing crop available for fall and winter grazers. Pre- and post-grazing clippings suggested heavy spring cattle grazing was responsible for disappearance of about $358 \mathrm{~kg} \mathrm{ha}^{-1}$ or about $70 \%$ of that difference. With our heavy-grazing treatments, about $30 \%$ of the total potential yield was unaccounted for. Again, conversions to litter or simply lost growth opportunities were most likely responsible.

Because we did not sort our pre- and post-grazing standing crop samples to

Table 3. Treatment $x$ year, species $x$ year, and year $x$ month interactions of percent in vitro organic matter disappearance of bluebunch wheatgrass, Idaho fescue, and bottlebrush squirreltail that were either ungrazed, lightly grazed, or heavily grazed by cattle at the boot stage of grass phenology and sampled the subsequent September and December on big game winter range near Burns, Ore. in 1998 and 1999. Paired "bold font" means within a column are significantly different $(P<0.05)$. Means within a row sharing a common letter are not significantly different $(\mathrm{P}>0$.05).

\begin{tabular}{|c|c|c|c|c|c|}
\hline \multirow{2}{*}{$\begin{array}{l}\text { Effect } \\
\text { Year }\end{array}$} & \multirow[b]{2}{*}{ Ungrazed } & \multicolumn{2}{|c|}{ Treatment } & \multicolumn{2}{|c|}{ Month } \\
\hline & & $\begin{array}{l}\text { Lightly } \\
\text { grazed }\end{array}$ & $\begin{array}{r}\text { Heavily } \\
\text { grazed }\end{array}$ & September & December \\
\hline $\begin{array}{l}1998 \\
1999\end{array}$ & $\begin{array}{l}49.5 \pm 1.3 \mathrm{a} \\
48.9 \pm 1.9 \mathrm{a}\end{array}$ & $\begin{array}{l}47.3 \pm 1.8 \mathrm{a} \\
58.4 \pm 2.0 \mathrm{~b}\end{array}$ & $\begin{array}{l}\underline{58.8} \pm 1.5 \mathrm{~b} \\
\underline{59.7} \pm 1.7 \mathrm{~b}\end{array}$ & $\begin{array}{l}47.6 \pm 0.7 a \\
59.5 \pm 1.8 a\end{array}$ & $\begin{array}{l}\underline{53.3} \pm 1.7 \mathrm{~b} \\
\underline{52.5} \pm 1.3 \mathrm{~b}\end{array}$ \\
\hline Effect & & Species & & & \\
\hline$\frac{\text { Season }}{\text { Sent }}$ & $\begin{array}{l}\text { Bluebunch } \\
\text { wheatgrass } \\
49.1+32 a\end{array}$ & $\begin{array}{l}\text { Idaho } \\
\text { fescue }\end{array}$ & $\begin{array}{l}\text { Bottlebrush } \\
\text { squirreltail }\end{array}$ & & \\
\hline $\begin{array}{l}\text { Sept } \\
\text { Dec. }\end{array}$ & $\begin{array}{l}49.1 \pm 3.2 \mathrm{a} \\
44.8 \pm 1.1 \mathrm{a}\end{array}$ & $\begin{array}{l}54.7 \pm 2.2 b \\
56.5 \pm 1.6 b\end{array}$ & $\begin{array}{l}56.8 \pm 2.1 b \\
55.9 \pm 1.3 b\end{array}$ & - & - \\
\hline
\end{tabular}

species, we cannot address treatment effects on individual species yields. Our September standing crop samples were sorted among species, however, and we experienced a year $\mathrm{x}$ species interaction in those analyses (Fig. 2). Moisture contributing to the 1998 growing season was 196 percent of average, but we cannot explain why bluebunch wheatgrass responded with an elevated regrowth yield in 1998 while the other 2 grasses did not.

\section{Crude protein}

Crude protein is only one of several important forage characteristics for rangeland herbivores. Among forages, however, $\mathrm{CP}$ levels are highly correlated with many desirable plant attributes such as digestibility and vitamin and mineral concentrations. Typically, all of these components decline to deficient levels at about the same time (Sullivan 1962). Thus, CP serves as a fairly reliable index of overall nutritional value, and much of our discussion will concentrate on this index of forage quality.

For the purpose of this discussion, we adopted a $7.5 \% \mathrm{CP}$ concentration as an adequate forage quality threshold. While considerable variation exists among sources regarding required $\mathrm{CP}$ concentrations on a dry matter basis for large herbivores, the $7.5 \%$ value typically equals or exceeds maintenance levels suggested for most North American wild and domestic ruminants (French et al. 1955, Thorne et al. 1976, Schwartz et al. 1977, Short 1981, Nelson and Leege 1982, NRC 1978, 1981, 1984). Among our grasses, there were 6 instances where fall and winter $\mathrm{CP}$ concentrations equaled or exceeded $7.5 \%$. Four of these occurred with bottlebrush squirreltail, 1 with Idaho fescue, and 1 with bluebunch wheatgrass (Fig 3). One instance of $\mathrm{CP} \geq$
$7.5 \%$ occurred in 1998 , and the remaining 5 were in 1999. Five instances of $\mathrm{CP} \geq 7.5$ percent were a product of heavy grazing, and 1 occurred in lightly grazed paddocks, again with bottlebrush squirreltail. In our ungrazed paddocks, September/December $\mathrm{CP}$ concentrations ranged between 2.4 and $5.3 \%$.

With 1 exception, a preponderance of our CP data suggested that elevated fall/winter forage quality in our grazed treatments was a product of summer regrowth. About 2 out of every 5 years, Pacific Northwest rangelands receive enough September/October precipitation to stimulate development of new tillers among bunchgrasses. In some instances, this can elevate fall forage quality (Ganskopp and Bohnert 2001), adding late season condition to both wildlife and livestock. Ganskopp and Bohnert (2001) detected fall green up and elevated CP among Sandberg's bluegrass (Poa sandbergii Vasey), cheatgrass (Bromus tectorum L.), bottlebrush squirreltail, and Idaho fescue in this same region. Bluebunch wheatgrass, however, did not exhibit that same pattern.

Both of our grazed bottlebrush squirreltail treatments in 1998 displayed increased CP concentrations between September and December (Fig. 3), suggesting some fall green-up had occurred. This did not occur, however, with Idaho fescue or bluebunch wheatgrass. In 1999, there was no evidence of fall green-up among any of our grasses, and we experienced some reduction of CP concentrations among all 3 species in our grazed treatments between September and December. Clark et al. (2000) described instances of increasing CP concentrations in bluebunch wheatgrass in Oregon's Blue Mountains between November and March, but they attributed those increases to a 
breakdown of lower quality standing litter rather than new growth.

As to the main effect of years, mean $\mathrm{CP}$ content for September/December was 4.95 $\pm 0.19 \%$ in 1998 and $5.76 \pm 0.32 \%$ in 1999 , with 1999 being the drier of the 2 years. This pattern of experiencing higherthan-expected forage quality with limited moisture regimes has been noticed by others in the region (Hedrick et al. 1969, Clark et al. 2000, Ganskopp and Bohnert 2001). This pattern appears to apply to forage mineral concentrations as well (Ganskopp and Bohnert 2003), and can generate enhanced livestock gains if quantity is not limiting (Hedrick et al. 1969). These annual disparities in forage quality are linked to less reproductive effort among grasses in drier years and a cured stand of younger leafy herbage.

With a reminder to readers that we experienced a nearly complete array of significant interaction effects with our CP data (Table 1 and Fig 3), we wish to briefly address species main effects. Across treatments, years, and months, mean CP concentrations were $6.5 \pm 2.3$, $5.2 \pm 1.4$, and $4.5 \pm 1.5$ for bottlebrush squirreltail, Idaho fescue, and bluebunch wheatgrass, respectively. Among grazed treatments on specific dates, bottlebrush squirreltail CP concentration exceeded Idaho fescue in 4 instances and was greater than bluebunch wheatgrass for all 8 comparisons between grazed treatments (Fig. 3). Grazed Idaho fescue CP concentration was higher than bluebunch in September and December of 1998, but all wheatgrass/fescue comparisons were similar in 1999. When Clark et al. (2000) conditioned Idaho fescue and bluebunch wheatgrass via sheep grazing, they also consistently reported higher CP concentrations for treated Idaho fescue than bluebunch wheatgrass.

If one's goal is to generate herbage with elevated fall/winter CP concentrations, then forage conditioning efforts will probably yield progressively greater returns from bluebunch wheatgrass, Idaho fescue, and bottlebrush squirreltail herbage, respectively. Although bluebunch wheatgrass is the most prevalent of grasses on mid-elevation Pacific Northwest and northern Great Basin rangelands (Daubenmire 1970, Hironaka et al. 1983), our results suggested that it may be the most difficult of the 3 species sampled to condition with livestock grazing.

Whether managers are responsible for wildlife or livestock, they typically try to keep their animals on an adequate plane of nutrition. For 3 out of 4 of our fall/winter sampling periods, one grass or another provided herbage with a CP concentration exceeding $7.5 \%$. Most often this occurred with our heavy grazing treatment (Fig. 3). Our only sub-maintenance period in the conditioned pastures occurred in September 1998. There, among our ungrazed controls, CP among the grasses never exceeded $4.7 \%$. However, managers should not despair when CP concentrations do not reach desired thresholds, because even small changes in forage quality can benefit animals accustomed to wintering on sub-maintenance diets (Albon and Langvatn 1992, Clark 1996). Also, large herbivores typically harvest diets of higher quality than simulated rations or whole-plant samples (Kiesling et al. 1969, McInnis and Vavra 1987, Cruz and Ganskopp 1998), so dietary CP concentrations for animals selectively grazing our paddocks would probably be higher than we expect.

\section{Neutral detergent fiber}

Neutral detergent fiber makes up the structural component of plant cell walls, and is the least digestible fraction of forage nutrients. That being the case, NDF is negatively correlated with forage digestibility and intake (Robinson 1999). High NDF values indicate a forage will be poorly digested and retention time extended in ruminants, and low values suggest much of the herbage will be rapidly digested and assimilated by the animal.

Among northern Great Basin grasses, NDF concentrations typically increase with maturity, varying from a springtime low of about $38 \%$ to an early winter high of $81 \%$ (Ganskopp and Bohnert 2001). In this study, mean September/December NDF concentration was $66.2 \%$. Treatment main effects were significant but did not contribute to any interactions. Ungrazed, lightly grazed, and heavily grazed means were $68.5 \pm 0.5,66.6 \pm 0.7$, and $63.2 \pm$ $0.7 \%$, respectively, with all comparisons being significant. A high/low treatment disparity of only $5 \%$ points, however, does not have much of a biological consequence. Basically, ruminants foraging in our control paddocks would have slightly lower passage rates and slightly less intake than companions in grazed treatments. Conversely, highest intake and the most rapid passage rates would be accomplished among the heavily grazed paddocks, but again treatment disparities border on being biologically inconsequential.

Among species of grass, bluebunch wheatgrass and Idaho fescue exhibited similar NDF concentrations between years. Bottlebrush squirreltail, however, had a slightly higher NDF concentration in $1998(65.7 \%)$ than $1999(62.7 \%)$. Also, September to December NDF concentrations remained stable among Idaho fescue and bottlebrush squirreltail, but increased about 3 percentage points for bluebunch wheatgrass (Table 2).

\section{In vitro organic matter disappearance}

In vitro organic matter disappearance is an assay of forage degradation or digestibility in the rumen. While treatment main effects were significant, a treatment $x$ year interaction $(P=0.006)$ indicated treatment responses were different between years (Table 1, Table 3). Mean IVOMD was approximately $49 \%$ in ungrazed paddocks and $59 \%$ in heavily grazed paddocks, with no differences between years within treatments. In lightly grazed paddocks, however, fall/winter IVOMD was lower in $1998(\bar{x}=47 \%)$ than in $1999(\bar{x}=58 \%)$. This disparity between years in the lightly grazed paddocks may have been related to the dilution of forage quality that we have seen occurring in above-normal precipitation years and addressed in our CP discussions above. With a spring forage utilization level of only $33 \%$ in our lightly grazed treatment, fall standing crop would be a mixture of ungrazed herbage and regrowth from grazed plants. Among our heavily grazed pastures, utilization was quite severe $(\bar{x}=60 \%)$, and a preponderance of the fall/winter standing crop was composed of current-year leafy regrowth. That being the case, year effects are probably less apparent with heavy grazing because most of the standing crop is composed of immature material.

Similarly, fall standing crop in our ungrazed paddocks was a mixture of cured materials generated during the current and previous 1 or 2 growing seasons. When these mixed- age materials are harvested and homogenized by grinding, we suspect that individual year effects on forage quality are quite buffered.

As to individual treatment effects September/December herbage in heavily grazed paddocks was about 10 percentage points more digestible than ungrazed and lightly grazed forage in 1998 (Table 3). In 1999, IVOMD was similar for both of the grazed treatments and again about 10 percentage points higher than our ungrazed treatment. Clearly, a $10 \%$ disparity in digestibility is biologically significant for a ruminant subsisting on a marginal diet.

Among species and months, IVOMD was similar for Idaho fescue and bottle 
brush squirreltail, and there was no decrease in digestibility between September and December for either species (Table 3). Bluebunch wheatgrass, however, was 5 to 10 percentage points less digestible than Idaho fescue or bottlebrush squirreltail, and it also displayed a September to December decline in IVOMD of about 5 percentage points $(\mathrm{P} \leq$ 0.01 ). These lower digestibility ratings for bluebunch wheatgrass again suggest it may be the most difficult of the 3 species sampled to condition with livestock grazing.

\section{Conclusions}

This study substantiates Anderson and Sherzinger's 1975 hypothesis that light (33\% utilization) and heavy (69\% utilization) spring cattle grazing of grasses during the boot stage of development can augment fall and winter forage quality for bluebunch wheatgrass, Idaho fescue, and bottlebrush squirreltail when compared with ungrazed stands. With $C P$ and IVOMD as indices of forage quality, heavy spring grazing, with its more uniform harvest of residual standing crop and elevated apical meristems, was more effective at forage conditioning than light grazing. Both grazing treatments, however, generated reductions in standing crop left for fall/winter livestock or big game use. Light grazing decreased fall standing crop by $32 \%$, while heavy grazing reduced standing crop by about $67 \%$ when compared to ungrazed stands. Among the 3 grasses and across the grazed treatments, mean September/December CP indices suggested conditioning efforts were most successful for bottlebrush squirreltail $(\overline{\mathrm{x}}=$ $7.4 \pm 0.01 \%)$, less so for Idaho fescue ( $\overline{\mathrm{x}}=$ $5.95 \pm 0.004 \%$ ), and least successful for bluebunch wheatgrass $(\bar{x}=4.9 \pm 0.01 \%)$. Our September/December IVOMD indices suggested that conditioned bottlebrush squirreltail $(\bar{x}=58.8 \pm 1.4 \%)$ and Idaho fescue $(\bar{x}=58.9 \pm 1.38 \%)$ were equally digestible and that conditioned bluebunch wheatgrass $(\bar{x}=49.5 \pm 1.44 \%)$ was about 10 percentage points less digestible. Yearly differences in precipitation affected fall standing crop and forage quality. As expected, fall standing crop was greater in the wetter of the 2 years sampled, however, assays of forage quality suggested herbage was more nutritious during the drier of the 2 growing seasons. We remind readers that the negative effects of grazing cool-season grasses at the boot stage of phenology are well documented. Judicious use of this practice is an option for managers, and it should probably be applied within a rotation program that allows rest or deferred use of a pasture every second and/or third year. Opportunity costs of spring time grazing also occur in that both annual and fall/winter standing crops will be reduced. The remaining herbage, however, will be nutritionally superior to ungrazed stands of grass reserved for fall and winter use by livestock or big game.

\section{Literature Cited}

Albon, S.D. and R. Langvatn. 1992. Plant phenology and the benefits of migration in a temperate ungulate. Oikos 65:502-513.

Anderson, E.W. and R.J. Scherzinger. 1975. Improving quality of winter forage for elk by cattle grazing. J. Range Manage. 28:120-125.

AOAC. 1984. Official methods of analysis (14 ${ }^{\text {th }}$ Ed.) Assoc. Official Analytical Chem. Wash. D.C.

AOAC. 1990. Official methods of analysis (15 $15^{\text {th }}$ Ed.) Assoc. Official Analytical Chem. Arlington, Virg.

Bedell, T.E. 1973. Clipping effects on growth form, yield and nutritive quality of crested wheatgrass in eastern Wyoming. Wyo. Agr. Exp. Sta. Res. J. 76.

Clark, P.E. 1996. Use of livestock to improve the quality of elk winter range forage in northeastern Oregon. Ph. D. Thesis, Ore. State Univ. Corvallis, Ore.

Clark, P.E., W.C. Krueger, L.D. Bryant, and D.R. Thomas. 1998a. Spring defoliation effects on bluebunch wheatgrass: I. winter forage quality. J. Range Manage. 51:519-525.

Clark, P.E., W.C. Krueger, L.D. Bryant, and D.R. Thomas. 1998b. Spring defoliation effects on bluebunch wheatgrass: II. basal area. J. Range Manage. 51:526-530.

Clark, P.E., W.C. Krueger, L.D. Bryant, and D.R. Thomas. 2000. Livestock grazing effects on forage quality of elk winter range. J. Range Manage. 53:97-105.

Cody R.P. and J.K. Smith. 1997. Applied Statistics and the SAS programming language. Prentice Hall, N.J.

Cruz, R. and D. Ganskopp. 1998. Seasonal preferences of steers for prominent northern Great Basin grasses. J. Range Manage. 51:557-565.

Daubenmire, R. 1970. Steppe vegetation of Washington. Wash. Agr. Exp. Sta., College of Agr. Wash. State Univ. Bull 62.

French, C.E., L.C. McEwen, N.D. Magruder, R.H. Ingram, and R.W. Swift. 1955. Nutritional requirements of white-tailed deer for growth and antler development. State College, Penn. Penn. Agr. Exp. Sta. Bull. 600.

Ganskopp, D. 1998. Thurber needlegrass: seasonal defoliation effects on forage quantity and quality. J. Range Manage. 51:276-281.
Ganskopp, D. and D. Bohnert. 2001. Nutritional dynamics of seven northern Great Basin grasses. J. Range Manage. 54:640-647.

Ganskopp, D. and D. Bohnert. 2003. Mineral concentration dynamics among seven northern Great Basin grasses. J. Range Manage. 56: 174-184.

Ganskopp, D., T. Svejcar, F. Taylor, J. Farstvedt, and K. Paintner. 1999. Seasonal cattle management in 3 to 5 year old bitterbrush stands. J. Range Manage. 52:166-173.

Hedrick, D.W., W. M. Moser, A.L. Steininger, and R.A. Long. 1969. Animal performance on crested wheatgrass pastures during May and June, Fort Rock, Oregon. J. Range Manage. 22:277-280.

Hironaka, M., M.A. Fosberg, and A.H. Winward. 1983. Sagebrush-grass habitat types of southern Idaho. Wildl. and Range Exp. Sta., Univ. of Ida., Moscow, Ida. Bull 35.

Hobbs, N. T., D.L. Baker, G.D. Bear, and D. C. Bowden. 1996. Ungulate grazing in sagebrush grassland: mechanisms of resource competition. Ecol. Appl. 6:200-217.

Hyder, D.N. and F.A. Sneva, 1963. Morphological and physiological factors affecting the grazing management of crested wheatgrass. Crop Sci. 3:267-271.

Kiesling, H.E., A.B. Nelson, and C. H. Herbel. 1969. Chemical composition of tobosa grass collected by hand-plucking and esophageal-fistulated steers. J. Range Manage. 22:155-159.

McInnis, M.L. and M. Vavra. 1987. Dietary relationships among feral horses, cattle, and pronghorn in southeastern Oregon. J. Range Manage. 40:60-66.

National Oceanic and Atmospheric Administration (NOAA). 2001. Climatological data annual summary, Oregon 107:13.

Nelson, J.R. and T.A. Leege. 1982. Nutritional requirements and food habits. p. 323-367 In: J.W. Thomas and D.E. Toweill (eds.) Elk of North America, ecology and management. Stackpole Books, Harrisburg, Penn.

NRC. 1978. Nutrient requirements of domestic animals. No. 6. Nutrient requirements of horses. Nat. Acad. Sci., Nat. Res. Counc., Wash. D.C

NRC. 1981. Nutrient requirements of domestic animals. No. 15. Nutrient requirements of goats. Nat. Acad. Sci., Nat. Res. Counc., Wash. D.C.

NRC. 1984. Nutrient requirements of domestic animals. No. 4. Nutrient requirements of beef cattle. Nat. Acad. Sci., Nat. Res. Counc., Wash. D.C

Petersen, R.G. 1985. Design and analysis of experiments. Marcel Dekker Inc., New York.

Pitt, M.D. 1986. Assessment of spring defoliation to improve fall forage quality of bluebunch wheatgrass (Agropyron spicatum). J. Range Manage. 39:175-181.

Robertson, J.B. and P.J. Van Soest. 1981. The detergent system of analysis and its application to human foods, p. 123-158. In: 
W.P.T. James and O. Theander (Ed.) The Analysis of dietary fiber. Marcell Dekker, N.Y.

Robinson, P.H. 1999. Neutral detergent fiber (NDF) and its role in alfalfa analyses. In: Proc. 29 California Alfalfa Symposium. Fresno, Cal.

Satterthwaite, F.E. 1946. An approximate distribution of estimates of variance components. Biometrics Bull. 2:110-114.

Schwartz, C.C., J.C. Nagy, and R.W. Rice. 1977. Pronghorn dietary quality relative to forage availability and other ruminants in Colorado. J. Wildl. Manage. 41:161-168.

Short, H.L. 1981. Nutrition and metabolism. In: O.C. Wallmo (ed.) Mule and black-tailed deer of North America. Univ. of Nebraska Press, Lincoln, Neb.
Skovlin, J.M., P.J. Edgerton, and B.R. McConnell. 1983. Elk use of winter range as affected by cattle grazing, fertilizing, and burning in southeastern Washington. J. Range Manage. 36:184-189.

Sneva, F.A. 1982. Relation of precipitation and temperature with yield of herbaceous plants in eastern Oregon. Int. J. Biometeor. 4:263-276.

Sullivan, J.T. 1962. Evaluation of forage crops by chemical analysis: a critique. Agron. $\mathbf{J}$. 54:511-515.

Thorne, E.T., R.E. Dean, and W.G. Hepworth. 1976. Nutrition during gestation in relation to successful reproduction in elk. J. Wild. Manage. 40:330-335.
Wambolt, C.L., M.R. Frisina, K.S. Douglass, and H.W. Sherwood. 1997. Grazing effects on nutritional quality of bluebunch wheatgrass for elk. J. Range Manage. 50:503-506.

Westenskow-Wall, K.J., W.C. Krueger, L.D. Bryant, and D.R. Thomas. 1994. Nutrient quality of bluebunch wheatgrass regrowth on elk winter range in relation to defoliation. J. Range Manage. 47:240-244. 